\title{
ОСОБЛИВОСТІ ПЕРЕЖИВАННЯ ПОЧУТТЯ ЩАСТЯ МОЛОДДЮ І ДОРОСЛИМИ В УМОВАХ ЗАХОДІВ ПРОТИДІЇ COVID-19
}

\author{
Алла Литвинчук \\ кандидат психологічних наук, \\ асистент кафедри психології розвитку та консультування \\ Житомирський державний університет імені Івана Франка \\ 10008, Україна, м. Житомир, вул. Велика Бердичівська, 40 \\ lytvynchukalla@gmail.com, https://orcid.org/0000-0001-9805-7416
}

\section{Тетяна Можаровська}

кандидат психологічних наук, старший викладач кафедри психології розвитку та консультування

Житомирський державний університет імені Івана Франка 10008, Україна, м. Житомир, вул. Велика Бердичівська, 40 mozharovska.t@gmail.com, https://orcid.org/0000-0001-9628-2994

\section{Анотація}

У статті розглянуто актуальність проблеми особливостей переживання почуття щастя в умовах самоізоляції, соціального дистанціювання, обмеження активності й карантинних заходів, пов'язаних із COVID-19. Розкрито особливості переживання почуттів різної модальності, зокрема, почуття щастя. Проаналізовано чинники та детермінанти впливу на емоційну сферу особистості. Визначено, що соціальні зв'язки є першочерговими для переживання почуття щастя. Такі соціальні контакти мають характеризуватись глибиною, якістю та частотою. Описано особливості почуття щастя залежно від його спрямованості: на стан «тут-і-тепер» і на спрямованість у майбутнє, а також наголошено на афективному, когнітивному та евдемоністичному компонентах щастя. Розроблено широку авторську форму-опитувальник, яка містить пакет різноспрямованих методів: опитувальник, елементи проективних методів (незакінчені речення), асоціативний метод, самоаналіз і самоспостереження, психодіагностична рефлексія. За допомогою зазначених вище методів емпірично встановлено, що почуття щастя молоді й дорослих характеризується ієрархією станів від більш до менш значущого: стан фізичного, психологічного, духовного благополуччя близьких, комфорту, безпеки і спокою, стан щастя як трансцендентне переживання, стан почуттєвої орієнтації на майбутнє. Існують відмінності в об'єктивному сприйнятті щастя та його суб'єктивному переживанні: здоров'я рідних і близьких поєднується з прагненням знаходитись у колі родини та найближчого оточення. Почуття щастя $\mathrm{y}$ респондентів загалом спродуковане здоров'ям, присутністю близьких, самоздійсненням, самоствердженням і досягненням цілей. Встановлено статистично значущий зв'язок між усвідомленням почуття власного щастя i наявністю стійких стосунків (родинних, сімейних, подружніх, романтичних, дружніх) (0,323); між усвідомленням щастя та частотою й рівнем соціальної активності, у які були включені досліджувані в докарантинний період $(0,221)$. Визначено, що щастя $є$ чинником подолання 
негативних переживань в умовах сучасних кризових трансформаційних суспільних процесів.

Ключові слова: емоційна сфера, почуття щастя, психологічна стабільність, юнацький вік, дорослість, кризовий стан суспільства.

\section{Вступ}

Світ сьогодні зазнає разючих, постійних, тривалих і раптових змін. Змін, до яких людство загалом і кожна людина зокрема не готові ні психологічно, ні економічно. Змінені умови існування суттєво вплинули на звичний спосіб життя окремої особистості, особливості її взаємодії зі світом, проявів іiї поведінки у навколишньому середовищі тощо. Зовнішні умови існування, життя, розвиток кожної особистості інтегровані у ії внутрішню картину світу, світобачення і світосприйняття, а відтак, у внутрішній світ особистості. Проблема особливостей переживання почуттів різної модальності на сучасному етапі розвитку суспільства стає джерелом психологічних розвідок і предметом наукових дискусій. Ситуація критичної нестабільності, психологічний тиск довкілля, перевантаження психіки, неконтрольовані джерела негативної інформації, високий рівень тривоги, як і специфічні трансформаційні процеси, у яких наразі опинилося суспільство, де окремий представник спільноти є пасивним спостерігачем, визначають необхідність підвищеної уваги науковців до різних аспектів емоційно-вольової сфери людини. Сучасні дослідники звертають увагу на негативні емоційні переживання i почуття, які їх зумовлюють. В умовах відсутності стабільності та постійності зовнішніх (економічних, політичних, соціальних) умов життєдіяльності особистості, має місце суттєве руйнування внутрішнього світобачення та орієнтації на зовнішній змінний світ. Так, звичні раніше цінності, ритуали, традиції, способи поведінки тощо сьогодні $\epsilon$ неадаптованими і невідповідними в умовах глобальної кризи людства (психологічної, економічної, соціальної, географічної, епідеміологічної тощо). Але, що ж дозволяє людині тримати внутрішній баланс між усіма раптовими змінами, непередбачуваними подіями, неочікуваними, певною мірою травмуючими і кризовими ситуаціями сьогодення? Чи можливо в умовах сьогоднішніх змін залишатися щасливими?

У Всесвітній доповіді про щастя (World Happiness Report), опублікованій підрозділом ООН з пошуку рішень стабільного розвитку (UN Sustainable Development Solutions Network) у 2020 році, утретє поспіль найбільш щасливою країною визнано Фінляндію. Наступні місця у рейтингу закріплені за Данією, Швейцарією, Ісландією та Норвегією. Україна в цьому рейтингу посіла лише 138 місце (Helliwell, Layard, Sachs \& De Neve, 2020). У «Доповіді про світове щастя 2020» вперше подано оцінку міст світу за їх суб'єктивним благополуччям і більш глибоко проаналізовано вплив соціального, міського i природного середовищ на почуття щастя. Таке триєдине поєднання - соціум, місто i природа як фактори впливу на почуття щастя - перегукуються з розвитком екологічної свідомості особистості, факторами впливу на яку визначено особистісний, соціальний і природний виміри становлення екологічної особистості підліткового віку (Можаровська, 2016). Для оцінки національного щастя використовується шість основних факторів: ВВП; соціальна підтримка; очікувана тривалість життя; свобода громадян самостійно приймати життєво важливі рішення; щедрість і ставлення до корупції. 
Результати найбільш тривалого (близько 80 років) в історії психології дослідження щастя, проведеного вченими Гарвардського університету, свідчать, що щасливими i здоровими люди відчувають себе за умови наявності в їхньому житті хороших стосунків (Waldinger, 2020). Р. Уолдінгер зазначив, що, по-перше, взаємозв'язок з іншими людьми є надзвичайно важливий для суб'єктивного почуття щастя; по-друге, важлива якість самих стосунків; по-третє, хороші, якісні стосунки покращують самопочуття (Waldinger, 2020).

Вивчення щастя, реалізоване Науково-дослідним інститутом щастя в Копенгагені (Данія) (Нарpiness Research Institute), свідчить про необхідність розрізняти почуття щастя тут-і-тепер і почуття щастя загалом, які відповідають афективному (емоційному) та когнітивному (пізнавальному) вимірам. М. Вікінг, генеральний директор Інституту, дослідник i науковець, відзначив, що афективний (гедоністичний) вимір щастя визначається повсякденними емоціями людей; когнітивний - роздумами та аналізом власного життя, і виокремив третій вимір щастя - евдемоністичний (Wiking, 2019). Останній, у свою чергу, спирається на аристотелівське визначення щастя, яке можна описати, як змістовне та цілеспрямоване життя.

Голландський соціолог, ініціатор дослідження щастя Рут Вінхонен підкреслив, що рівень щастя, який демонструють люди, що рівнозначний із рівнем здоров'я i життєзабезпечення, є одним із найбільш значущих показників комфортності та належності суспільства й спільноти для життя окремої людини (Veenhonen, 1991). Р. Лейард вважає, що врахування прагнення до щастя окремої особистості повинно виступати базою для політичних, економічних і державних рішень (Лэйард, 2011).

Мета дослідження: теоретично вивчити особливості емоційного стану людей із впровадженням карантинних заходів по боротьбі з COVID-19 (режимом обмеження соціальних контактів, самоізоляції, дистанційного навчання/роботи); емпірично дослідити основні аспекти переживання почуття щастя молоддю і дорослими в новітніх кризових трансформаційних умовах. Завдання дослідження: 1) здійснити теоретичний аналіз підходів вітчизняних і зарубіжних вчених щодо особливостей переживання позитивних почуттів у кризових умовах; 2) емпірично дослідити психологічні особливості переживання почуття щастя молоддю і дорослими в умовах трансформації сучасного суспільства та зіставити їх із результатами сучасних досліджень.

\section{Методи дослідження}

Для виконання визначених завдань була використана низка методів, які відповідають поставленій меті: теоретичні (аналіз вітчизняних і зарубіжних джерел, узагальнення теорій i підходів, порівняння, систематизація) для обгрунтування теоретичних засад і передумов особливостей переживання почуття щастя у ситуації кризи та емпіричні (опитування, анкетування, методика незакінчених речень, самоаналіз, збір супутньої інформації, контент-аналіз, методи математичної статистики) для дослідження рівня, інтенсивності, глибини і частоти почуттів у кризових ситуаціях, що продукують підвищений рівень тривожності.

Для вивчення досліджуваного феномена автори статті розробили он-лайн форму, що дозволяє дистанційно дослідити окремі сторони почуттів населення у період пандемії. Інструментарій дослідження включає чотири логічно пов'язані між собою складові частини-розділи, які містять у собі набір різнопланових способів діагностики: анкета, 
проективні методики, метод асоціацій тощо. Зважаючи на специфіку інструментарію дослідження та його авторський характер, вважаємо доцільним детальніше конкретизувати склад і зміст он-лайн форми.

Перший - вступний розділ має на меті збір таких загальних даних: псевдонім, вік, сфера діяльності (професія, навчання), місце проживання (місто, село, селище), стать. Для індексу статі, крім жіночої та чоловічої, для підвищення рівня інклюзивності та прозорості, була встановлена можливість відзначати власний варіант.

Другий розділ форми спрямований власне на дослідження почуття щастя, як суб'єктивного прояву свого наявного актуального стану. Переважна більшість тверджень, передбачених розділом, мають проективний характер. Респондентам було запропоновано у довільній наративній формі пояснити власне розуміння поняття «щастя» через продовження тверджень «для мене щастя це - ...», «я почуваюсь щасливим(-ою), коли...». Також важливим $є$ встановлення інтервальності та часових характеристик почуттів: «останній раз я почував(-ла) себе щасливим (-ою), коли...» та «чи почуваюся я зараз щасливим(- ою)?», «остання ситуація, яка викликала у мене сміх була, коли (опишіть іiі, навіть, якщо вона незначна)...». Окрім встановлення згаданих вище даних, у цьому розділі визначені також два питання, які спрямовані в майбутню часову перспективу опитуваних осіб i демонструють їх загальний психоемоційний стан: «у мене $\epsilon$ чітка мрія (плани/ціль/мета)» та «я живу відповідно до своєї мрії». Останнім пунктом цього розділу є використання методу асоціацій. Респондентам пропонувалося зазначити п'ятнадцять асоціацій на слово-стимул «щастя».

Третій розділ форми має на меті збір супровідної інформації для глибшого аналізу отриманих даних та виокремлення можливих додаткових чинників і детермінант чуттєвої сфери. Супровідна інформація визначає, в якому стані психологічного, соціального, фізичного i матеріального благополуччя досліджувані опинились у режимі обмежувальних заходів (самоізоляція, карантин, соціальна дистанція). До інформації, яка вміщена до розділу, належать запитання про рівень доходу та задоволеності ним, наявність/відсутність власного житла, проживання 3 сім'єю/родичами чи самостійно, наявність стосунків, рівень підтримки фізичного стану (відвідування тренажерної зали чи відсутність фізичної активності взагалі), розподіл і витрата вільного часу (книги, фільми тощо), наявність хобі, рівень соціальної активності.

Четвертим розділом форми передбачено встановлення зворотного зв'язку та отримання інформації, яка $\epsilon$ актуальною для респондентів, але не була додана до загального переліку 3 об’єктивних причин. Респондентам пропонувалося описати твердження, на які їм самим було б цікаво відповісти, або, які вони вважали б вартими зарахування у запропонований варіант форми.

\section{Результати та дискусії}

3 метою виконання першого завдання дослідження були проаналізовані сучасні підходи до визначення феномена «щастя». Вивчення феномена «щастя» $є$ достеменним свідченням того, що існує широке коло підходів до визначення самого поняття. Зокрема, у «Великому психологічному словнику» термін «щастя» описано як «задоволеність» (англ. - satisfaction) і визначається як суб'єктивна оцінка якості тих чи інших об'єктів, умов життєдіяльності, життя в цілому, взаємин з людьми (іншими), самих людей, зокрема і себе 
(самооцінка). Відзначено, що високий рівень задоволеності життям визначається, як «щастя» (англ. - happiness) (Мещеряков \& Зінченко, 2008: 507).

Очевидно, психологічний аспект щастя пов'язаний з розумінням феномена, як оптимального, здорового, ефективного функціонування особистості, в основу якого покладено суб'єктивне відчуття задоволеності життям.

Відповідно до другого завдання, яке зазначено у публікації, до емпіричного дослідження залучено 81 респондента віком від 18 до 61 року, з них - 75 жінок і 6 чоловіків. Он-лайн опитування, як дистанційний, слабо контрольований дослідниками процес збору даних, забезпечило швидке і дифузне поширення форми опитувальника. Беручи це до уваги, вважаємо за необхідне схарактеризувати особливості вибірки. Сфера зайнятості виявилася досить широкою: більшість респондентів працюють у різних сферах або навчаються у закладах вищої освіти. В дослідженні взяли участь психологи, викладачі, вчителі, асистенти вчителя, педагоги-організатори, державні службовці, науковці, військовослужбовці, соціальні працівники, медичні працівники, поштарі, бухгалтери, юристи, електрики, домогосподарі, приватні підприємці, рекрутери тощо.

Щодо рівня урбанізованості респондентів, то переважна більшість опитаних осіб проживають у місті (80,4\%), жителями сільської місцевості є лише 19,6\%, зокрема 1,2\% періодично проживають в місті на період навчання або роботи. В дослідженні взяли участь респонденти з різним рівнем соціальної забезпеченості. Їх значна частина забезпечена власним житлом $(51,2 \%)$, на другому місці знаходиться проживання у гуртожитку, що очевидно пов'язане зі значною кількістю опитаних студентів. На третьому місці знаходиться самостійне винаймання приватного житла $(8,5 \%)$. Також зустрічаються варіанти спільної оренди, проживання спільно з родичами, друзями тощо. Проте, лише 7,3\% з опитаних осіб відповіли, що проживають самостійно, решта впродовж самоізоляції ділить житло 3 (у порядку спадання) батьками $(23,2 \%)$, друзями $(14,6 \%)$, родичами $(4,9 \%)$ та ін.

Щодо психоемоційних чинників, то переважна більшість респондентів знаходяться у стосунках $(84,2 \%)$, лише $14,6 \%$ - наразі не мають близьких стосунків, 1,2\% переживають розрив/розлучення. Позаробочий і позанавчальний час опитані особи розподіляють між активним і пасивним відпочинком. Водночас пасивний інтравертований відпочинок переважає зі значним розривом. Свій вільний час респонденти найчастіше присвячують перегляду фільмів (52,4\%), читанню $(37,8 \%)$, відпочинку, у формі активного соціального життя, зокрема, зустрічі з друзями (41,5\%). Ресурсним заняттям, якими зайнятий вільний час, віддають перевагу невелика кількість респондентів $(14,8 \%)$. Серед таких занять можна виокремити: творчі (малювання, спів), самоосвіту (пізнавальні лекції, наукова діяльність тощо), а також спілкування з рідними та близькими людьми (дітьми, коханими). Активну підтримку фізичного стану жоден з респондентів не зарахував до занять, якими вони насичують свій день. Проте, при уточнюючому запитанні виявилось, що третина респондентів займаються спортом - вдома $(31,7 \%)$ або відвідують спортзали (12,2\%). Їх фізична активність триває від 1 до 3 вільних годин щодня. Саме стільки вільного часу вдома має переважна більшість респондентів, невелика кількість опитаних осіб має від 5 до 8 вільних годин на день (8,5\%). Загалом спостерігається різке зменшення вільного часу 3 введенням карантинних заходів. Респонденти відзначили, що «до карантину мали 2-3 години вільного часу, зараз - набагато менше». Очевидно, чинників 
зменшення кількості вільного часу $є$ кілька: різка зміна способу життя, розклад дня, планування справ, переорієнтація на нові умови, пристосування до змінених форм робочої та навчальної діяльності тощо.

Зважаючи на зазначені вище особливості та очевидну нерівномірність, а, відтак, специфіку вибірки, в подальшому вважаємо доцільним здійснити якісний аналіз уявлень про щастя без порівняльного зіставлення статевих відмінностей переживання почуття щастя чоловіками і жінками. Однак, беручи до уваги велику кількість респондентів жіночої статі, не можемо залишити поза увагою окремий аналіз специфіки переживання жінками почуття щастя.

Для всіх жінок, незалежно від віку, категорії розуміння почуття щастя можна виокремити у кілька великих окремих блоків. Першим, за частотою згадування, $\epsilon$ розуміння почуття щзастя через стан фізичного, психологічного, духовного благополуччя близьких. Опитані особи наголосили на тому, що щастя для них - це, в першу чергу (прим. авт. - тут і далі цитування зі збереженням стилістики), «розуміння того, що мої близькі і рідні здорові», «коли всі мої біля мене і здорові», «коли всі рідні здорові і живі», «здоров'я», «здорові та щасливі діти», «здоров'я близьких». Це очікувані передбачувані результати, які співзвучні із зарубіжними психологічними дослідженнями почуттєвої сфери в ситуації переживання Covid-19 (Wang, Pan, Wan, Tan, Xu, Ho \& Ho, 2020; Caо, Fang, Hou, Han, Xu, Dong \& Zheng, 2020). Другим, за частотою згадувань, є розуміння щзастя як комфорт $i$ безпека/спокій, які респонденти описували через поняття емоційної сфери: «усвідомлення почуття внутрішнього комфорту», «усвідомлення того, що ти задоволений, усміхнений», «душевний спокій», «почуття безтурботності», «спокій i рівновага», «позитивні емоції, посмішка». Третім виявилась характеристика щзастя як трансцендентного переживання: «гармонія», «вершинні переживання», любов, наповненість, добро». Зазвичай, саме ці характеристики виокремлені, як основоположні для переживання почуття щастя (World Health Organization, 2020). Проте, в ситуації неконтрольованої та невизначеної загрози власному життю та, що, найважливіше для респондентів - загрози життю близьких, вони не так часто згадувалися, як попередні. Наступним блоком є почуттєва орієнтація на майбутнє: «сенс мого життя», «робити те, що хочеться і коли хочеться».

Контент-аналіз дозволив виокремити основні категорії, якими респонденти описують почуття щастя на початку введення карантинних заходів. Для них щастя визначається, як: здоров'я близьких, сім'я, діти, любов, гармонія, спокій, впевненість, злагодженість, рівновага.

Водночас помічені певні особливості у загальному об'єктивному прояві щастя та чинників переживання щастя для конкретного суб'єкта. На першому місці все ще зберігається фокус на родинних зв'язках. Проте, акцент зміщується зі здоров'я близьких на присутність поряд та їх психоемоційні стани. Респонденти почуваються щасливими, коли «поряд кохана людина», «моя родина - біля мене», «щасливі мої рідні», «я та мої рідні здорові», «щасливі мої діти, коли кохані люди поруч», «коли поруч є люди, яких я люблю».

На другому місці виявилися суб'єктифікація та концентрація на собі. Опитані особи відзначили таке: вважаю себе щасливим, коли «почуваю себе добре і задіяна у справах», «досягаю мети», «мене хвалять, спілкуються зі мною щиро...», «вільна та 
наповнена», «відчуваю любов, піклування...», «мене люблять». Також згадується активна діяльність, яка забезпечує почуття щастя: «можу допомагати людям», «роблю щось приємне чи хороше для інших людей», «досягаю мети», «роблю те, що мені подобається». Також для респондентів важливою умовою почуття щастя є присутність коханої людини.

Цікаво зауважити, що власний фізичний стан не є визначальною характеристикою почуття щастя. Про нього з семидесяти п'яти респондентів згадують лише двоє і у загальних висловах: «гарно виглядаю», «я та мої рідні здорові». За результатами контентаналізу можна стверджувати, що почуття щастя опитаних осіб загалом спродуковане здоров'ям, присутністю близьких, самоздійсненням, самоствердженням і досягненням цілей.

Позитивний емоційний заряд востаннє респонденти отримували, коли переживали інтимні родинні та сімейні моменти, спілкувались із дітьми, з друзями, а також у дуже загальних ситуаціях, які не мали на меті розсмішити, але сприйнялись, як смішні.

Тенденція залежності почуття щастя не лише від фізичного здоров'я рідних, а й від успішної реалізації задуманих цілей простежується на всіх етапах дослідження. Так, 96,2\% респондентів відповіли ствердно на запитання чи є у них чітка мрія, до якої вони прагнуть; 96,5\% опитаних осіб, маючи чітку мрію, будують своє життя так, щоб здійснити iii, ще 3,8\% осіб намагаються змінити своє життя відповідно до мрій, решті - поки не вдається цього зробити.

Результати дослідження 3 використанням елементів асоціативного методу підтверджують показники, отримані за методикою незакінчених речень. Ієрархія слівасоціацій до слова-стимулу «щастя» розподілилась таким чином: сім'я, любов, кохання, здоров'я, друзі, позитивні емоції, мрія, успіх, навчання, гармонія, відпочинок, робота, спокій, задоволення. Отримані дані підтверджено у результатах інших досліджень про особливості рефлексії емоційних станів, зокрема, емпатійність у юнацькому віці (Литвинчук, 2016). Очевидним є їх об'єднання у кілька стійких груп за схожими характеристиками: 1) сім'я та родинні зв'язки, які виступають ядром і центром; 2) близьке оточення, яке забезпечує соціальний комфорт (друзі); 3) суб'єктивні переживання: мрії, гармонія, спокій; 4) джерела й шляхи самореалізації: відпочинок і робота.

Вік респондентів чоловічої статі - від 18 до 35 років. Вони $є$ представниками різних сфер діяльності та різного рівня урбанізованості.

Варто відзначити, що результати методики незакінчених речень - досить лаконічні й стислі визначення чоловіками поняття «щастя». Розуміння чоловіками почуття щастя можна описати узагальнено, адже їх відповіді виявилися різними i, через невелику вибірку складно піддаються систематизації. Так, наприклад, «здоров’я близьких та рідних» зустрічається один раз, одночасно з іншими уточнюючими характеристиками, такими як «взаємне та щире кохання». Опис щастя зводиться до понять «коли добре» і «спокій». Також зустрічаються відповіді, які демонструють спрямованість на соціум: «друзі», «коли поблизу споріднені душі», та результативність - «якісний діалог». Загалом, все ж можна виокремити певну тенденцію, де щастя, в першу чергу, $\epsilon$ результатом успішної міжособистісної взаємодії, на другому місці знаходиться щастя, як позитивний психоемоційний стан, і на третьому місці - щастя, як благополуччя близьких.

Суб'єктифікація чоловіків також має певні закономірності. На першому місці знаходиться результативність і продуктивність, а також орієнтація на результат. 
Респонденти стверджують, що почуваються щасливими, коли: «зміг чимось допомогти», «в мене щось виходить», «завершую справу, або приходить розуміння...». На другому місці знаходяться характеристики внутрішніх психоемоційних станів: «мені добре», «заспокоєний». Спілкування та порозуміння з близькими зустрічається лише один раз.

Позитивний емоційний заряд востаннє отримували респонденти, коли спілкувалися 3 друзями та рідними, а також перебували разом 3 коханою людиною. Переживання вимушеної самоізоляції та карантинних заходів для чоловіків виявилось значущим джерелом позитивних емоцій. У жінок, не зважаючи на велику кількість, таких відповідей не зустрічається. Ситуація, яка викликала посмішку, була спровокована дуже чіткими зовнішніми умовами, які, власне, мають на меті розсмішити: «мем про коронавірус», «побачив мем», «розповідь друга...», «дивився новини». Частина опитаних осіб не змогла дати відповідь, що ж змусило їх посміхатися. Переважна більшість респондентів $(98,1 \%)$ має чітку життєву мрію та цілеспрямовано прямує до ії реалізації (96,9\%).

Результати елементів асоціативного методу та ієрархія слів-асоціацій дозволили виокремити такі аналогії слова «щастя»: здоров'я, любов, сім'я, спокій, відпочинок, зустріч, рух. Очевидно їх можна групувати за щонайменше трьома категоріями: щастя як сімейні зв'язки, щастя як стан переживань і щастя як спрямованість.

До отриманих результатів загальної вибірки було застосовано метод лінійної кореляції. Щодо наявності почуття щастя й актуальних соціоматеріальних i психоемоційних станів, були виявлені певні закономірності (див. табл. 1), які схожі 3 аналогічними зарубіжними дослідженнями (Oosterhoff, 2020).

Таблиия 1

Значущі коефіцієнти кореляцій між показниками усвідомленості почуття щастя та психосоціального стану досліджуваних

\begin{tabular}{|l|c|c|c|c|c|}
\hline \multirow{2}{*}{$\begin{array}{c}\text { Рівень } \\
\text { усвідомлення } \\
\text { почуття щастя }\end{array}$} & $\begin{array}{c}\text { Стійкі } \\
\text { тривалі } \\
\text { стосунки }\end{array}$ & $\begin{array}{c}\text { Матеріальна } \\
\text { стабільність }\end{array}$ & $\begin{array}{c}\text { Соціальні } \\
\text { активності }\end{array}$ & $\begin{array}{c}\text { Власне } \\
\text { благополуччя }\end{array}$ & $\begin{array}{c}\text { Активна } \\
\text { життєва } \\
\text { позиція }\end{array}$ \\
\hline Високий & $0,323^{*}$ & 0,205 & $0,221^{*}$ & 0,197 & 0,217 \\
\hline Середній & 0,158 & 0,202 & 0,201 & 0,160 & 0,172 \\
\hline Низький & 0,163 & 0,184 & 0,174 & 0,198 & 0,193 \\
\hline
\end{tabular}

Примітка: позначення * - значущість зв'язку на рівні $p \leq 0,01$.

Як видно $з$ табл. 1, існує статистично значущий зв'язок $(\mathrm{p}<0,01)$ :

- між усвідомленням почуття власного щастя та наявністю стійких стосунків (родинних, сімейних, подружніх, романтичних, дружніх) (0,323);

- між усвідомленням щастя і частотою та рівнем соціальної активності респондентів у докарантинний період $(0,221)$.

Не можна $з$ упевненістю стверджувати про наявність статистично значущих зв'язків між рівнем матеріальної забезпеченості, наявністю власного житла, відвідуванням (до впровадження обмежувальних заходів) розважальних центрів і кафе та відчуттям щастя. Проте, зважаючи на чисельність вибірки та їі неоднорідність, очевидно, дослідження вимагає розширення кола респондентів за віковим і статевим критерієм. Вважаємо, що доцільно зазначити про існування певної специфіки переживання почуття щастя у період пандемії COVID-19: почуття щастя виступає одночасно чинником та умовою стратегій 
подолання негативних психоемоційних станів в умовах сучасних кризових трансформаційних суспільних процесів.

\section{Висновки}

Звісно, розкритий вище аналіз психологічних особливостей переживання респондентами почуття щастя у період COVID-19, не вичерпує усіх можливих особливостей переживань позитивних почуттів і може уточнюватись і доповнюватись, зважаючи на широту та рівномірність вибірки. Встановлено, що не існує однозначного і вичерпного погляду на поняття «щастя». Феномен пов'язаний з явищами духовного, психологічного, соціального та фізичного благополуччя. Почуття щастя наділено високою суб'єктивністю.

Презентовані емпіричні дані свідчать, що існують відмінності у переживанні почуття щастя у період COVID-19. Трактування почуття щастя виокремлено у чотири групи: 1) стан фізичного, психологічного, духовного благополуччя; 2) комфорт і безпека (спокій); 3) трансцендентне переживання; 4) почуттєва орієнтація на майбутнє. Констатовано наявність статистично значущих зв'язків між почуттям щастя та тісними емоційними стосунками і рівнем соціальної активності.

Перспективи подальших розвідок вбачаємо у серії повторних досліджень переживання чоловіками і жінками почуття щастя під час посилення карантинних заходів i, згодом, у період відміни обмежувальних заходів; у поглибленому вивченні розуміння ними щастя. Стадіальні поперечні зрізи дозволять визначити поступову динаміку та зміни психоемоційного стану впродовж критичних трансформаційних суспільних процесів.

\section{Література}

1. Аргайл, М. (2003). Психология счастья. Санкт-Петербург : Питер.

2. Литвинчук, А.I. (2016). Рефлексія емпатійних переживань в юнацькому віці: екологічний аспект. Наука $i$ освіта, 5, 200-205. Режим доступу: http://eprints.zu.edu.ua/id/eprint/23279

3. Лэйард, Р. (2011). Счастье: уроки новой науки. Москва : Изд-во Института Гайдара.

4. Мещеряков, Б.Г., \& Зинченко, В.П. (2008). Большой психологический словарь. Режим доступу: https://www.gumer.info/bibliotek_Buks/Psihol/dict/19.php

5. Можаровська, Т.В. (2016). Структурно-динамічна модель розвитку екологічної свідомості. Наука і освіта. 5, 124-130. Режим доступу: http://eprints.zu.edu.ua/23275/.

6. $2^{\text {nd }}$ OECD World Forum. (2007). Istambul. Режим доступу: https://www.oecd.org/site/ worldforum06/istanbulworldforum-measuringandfosteringtheprogressofsocieties.htm

7. Cao, W., Fang, Z., Hou, G., Han, M., Xu, X., Dong, J., \& Zheng, J. (2020). The psychological impact of the COVID-19 epidemic on college students in China. Psychiatry Research, 112-934.

8. Helliwell, J.F., Layard, R., Sachs, J., \& De Neve, J.E. (2020). World Happiness Report. Sustainable Development Solutions Network. New York.

9. Meik, Wiking. (2019) The Little Book of Lykke.

Режим доступу: https://www.happinessresearchinstitute.com/publications/

10. Oosterhoff, B. (2020). Psychological correlates of news monitoring, social distancing, disinfecting, and hoarding behaviors among US adolescents during the COVID-19 pandemic. Режим доступу: https://psyarxiv.com/rpcy4/ 
11. Veenhoven, R. (1991) Questions on happiness: Classical topics, modern ansvers, blind spots. Subjective Well-Being: An Interdisciplinaru Perspective 7-26, 14. England : Oxford.

12. Wang, C., Pan, R., Wan, X., Tan, Y., Xu, L., Ho, C.S., \& Ho, R.C. (2020). Immediate psychological responses and associated factors during the initial stage of the 2019 coronavirus disease (COVID-19) epidemic among the general population in China. International Journal of Environmental Research and Public Health, 17(5), 1729.

13. Waldinger, R. (2020). What makes a good life? Режим доступу: https://robertwaldinger.com/

14. World Health Organization. (2020). Mental health and psychosocial considerations during the COVID-19 outbreak, 18 March 2020 (No. WHO/2019-nCoV/MentalHealth/2020.1).

\section{References}

1. Argail, M. (2003). Psykhologya schastya [Psychology of Happiness]. Sankt-Peterburh : Pyter [In Russian].

2. Lytvynchuk, A.I. (2016). Refleksya empatiynuh perezhyvan v yunatskomu vitsi: ekolohichnyi aspect [The reflection of empathic experiences in adolescence: the ecological aspect]. Nauka $i$ osvita - Science and education, 5, 200-205. Retrieved from http://eprints.zu.edu.ua/id/eprint/23279 [In Ukrainian].

3. Leiard, R. (2011). Schaste: uroky novoi nauky [Happiness: New science lessons]. Moskva : Yzd-vo Ynstytuta Haydara [In Russian].

4. Meshcheriakov, B.G., \& Zynchenko, V.P. (2008). Bolshoi psykholohycheskyi slovar [A big psychological dictionary]. Retrieved from https://www.gumer.info/bibliotek_Buks/ Psihol/dict/19.php [In Russian].

5. Mozharovska, T.V. (2016). Strukturno-dynamichna model rozvytku ekolohichnoi svidomosti [Structural-dynamic model of the development of ecological consciousness]. Nauka i osvita - Science and education, 5, 124-130. Retrieved from http://eprints.zu.edu.ua/23275/ [In Ukrainian].

6. $2^{\text {nd }}$ OECD World Forum. (2007). Istambul. Retrieved from https://www.oecd.org/site/ worldforum06/istanbulworldforum-measuringandfosteringtheprogressofsocieties.htm

7. Cao, W., Fang, Z., Hou, G., Han, M., Xu, X., Dong, J., \& Zheng, J. (2020). The psychological impact of the COVID-19 epidemic on college students in China. Psychiatry Research, 112-934.

8. Helliwell, J.F., Layard, R., Sachs, J., \& De Neve, J.E. (2020) World Happiness Report. Sustainable Development Solutions Network. New York.

9. Meik, Wiking. The Little Book of Lykke.

Retrieved from https://www.happinessresearchinstitute.com/publications/

10. Oosterhoff, B. (2020). Psychological correlates of news monitoring, social distancing, disinfecting, and hoarding behaviors among US adolescents during the COVID-19 pandemic. Retrieved from https://psyarxiv.com/rpcy4/

11. Veenhoven, R. (1991) Questions on happiness: Classical topics, modern ansvers, blind spots. Subjective Well-Being: An Interdisciplinaru Perspective 7-26, 14. England : Oxford.

12. Wang, C., Pan, R., Wan, X., Tan, Y., Xu, L., Ho, C.S., \& Ho, R.C. (2020). Immediate psychological responses and associated factors during the initial stage of the 2019 coronavirus disease (COVID-19) epidemic among the general population in China. International Journal of Environmental Research and Public Health, 17(5), 1729.

13. Waldinger, R. (2020). What makes a good life? Retrieved from https://robertwaldinger.com/

14. World Health Organization. (2020). Mental health and psychosocial considerations during the COVID-19 outbreak, 18 March 2020 (No. WHO/2019-nCoV/Mental Health/2020.1). 


\title{
FEAUTERES OF EXPERIENCING FEELINGS OF HAPPINESS OF YOUTH AND \\ ADULTS IN THE COVID-19 COUNTERACTION
}

Alla Lytvynchuk

PhD in Psychology, Lecturer of the Department of

the Developmental Psychology and Counseling

Zhytomyr Ivan Franko State University

40, Velyka Berdychivska Str., Zhytomyr, Ukraine, 10008

lytvynchukalla@gmail.com, https://orcid.org/0000-0001-9805-7416

Tetiana Mozharovska

PhD in Psychology, Lecturer of the Department of

the Developmental Psychology and Counseling

Zhytomyr Ivan Franko State University

40, Velyka Berdychivska Str., Zhytomyr, Ukraine, 10008

mozharovska.t@gmail.com, https://orcid.org/0000-0001-9628-2994

\begin{abstract}
The article discusses the relevance of the problem of the features of experiencing feelings of happiness in conditions of self-isolation, social distance, limited activities and quarantine activities related to COVID-19. Revealed the features of experiencing feelings of different modality, in particular a sense of happiness. Analyzed the factors and determinants of the impact on the emotional sphere of the personality. It is determined that social ties are the primary ones for experiencing feelings of happiness. These social contacts characterized by depth, quality and frequency. Described the features of a sense of happiness depending on its orientation: to the state of "here and now" and orientation to the future, as well as the affective, cognitive and eudemonistic components of happiness. A wide author's questionnaire form developed, which contains a package of multidirectional methods: elements of projective methods (unfinished sentences), associative method, introspection and self-observation, psycho-diagnostic reflection). Applying these methods it been empirically established that a sense of happiness of youth and adults characterized by a hierarchy of states from more to less significant: the state of physical, psychological, spiritual well-being of loved ones, comfort, safety and tranquility, the state of happiness as a transcendental experience, the state of sensory orientation to the future. There are differences in the objective perception of happiness and its subjective experience: the health of loved ones combined with the desire to be in the circle of the family and the immediate environment. The feeling of happiness of the subjects as a whole determined by health, the presence of loved ones, self-realization, self-affirmation and achievement of goals. A statistically significant relationship was established between awareness of feelings of own happiness and the presence of stable relationships (family, family, marital, romantic, friendly) (0.323) between awareness of happiness and the frequency and level of social activities in which the subjects were included (0.221). It is described that happiness is the determinant and condition of the way to overcome negative experiences in modern crisis transformational social processes.
\end{abstract}

Keywords: emotional sphere, a sense of happiness, youth, adulthood, a crisis of society.

Подано 26.04.2020

Рекомендовано до друку 10.06.2020 